\title{
REALIZACJA SZCZEPIEŃ OCHRONNYCH U DZIECI DO DRUGIEGO ROKU ŻYCIA
}

\author{
IMPLEMENTATION OF VACCINATION IN CHILDREN UP TO THE AGE OF TWO
}

\author{
Anna Katarzyna Kędzierska ${ }^{1, \text { a }}$, Małgorzata Ochman-Zawilińska², Joanna Owsianowska ${ }^{1, b}$, \\ Katarzyna Kowalczyk ${ }^{2}$, Sylwia Wieder-Huszla ${ }^{1, c}$, Katarzyna Grabowiecka ${ }^{3}$, Anna Jurczak ${ }^{1,}$ \\ ${ }^{1}$ Zakład Pielęgniarstwa Specjalistycznego, Pomorski Uniwersytet Medyczny w Szczecinie \\ ${ }^{2}$ Koło Naukowe Zakładu Pielęgniarstwa Specjalistycznego, Pomorski Uniwersytet Medyczny w Szczecinie \\ ${ }^{3} 109$ Szpital Wojskowy z Przychodnią Samodzielny Publiczny Zakład Opieki Zdrowotnej \\ ${ }^{a}$ https://orcid.org/0000-0002-5772-2536 \\ ${ }^{\mathrm{b}} \mathrm{https}: / /$ orcid.org/0000-0001-9096-8477 \\ ${ }^{c}$ https://orcid.org/0000-0002-6084-5780 \\ ${ }^{d}$ https://orcid.org/0000-0003-1935-5285
}

DOI: https://doi.org/10.20883/pielpol.2019.33

\section{STRESZCZENIE}

Wstęp. W Polsce szczepienia odbywają się w podmiotach leczniczych i prowadzone są przez lekarzy, pielęgniarki i położne. Osoby, które przebywają na terenie Rzeczypospolitej Polskiej powyżej 3 miesięcy mają obowiązek poddać się szczepieniom ochronnym przeciwko chorobom zakaźnym zgodnie z obowiązującym Programem Szczepień Ochronnych.

Cel. Celem pracy było określenie czynników decydujących o realizacji zalecanych szczepień ochronnych u dzieci do 2 roku życia.

Materiał i metody. W badaniu uczestniczyło 300 respondentów (rodziców dzieci do drugiego roku życia) 91\% kobiet i 9\% mężczyzn. Badania przeprowadzono w poradniach pediatrycznych i lekarza rodzinnego na terenie miasta Szczecin. W badaniach wykorzystano kwestionariusz autorskiej ankiety zawierającej dane socjodemograficzne oraz pytania z zakresu szczepień ochronnych.

Wyniki. Ponad $78,67 \%$ badanych rodziców podało, że ich dziecko jest szczepione zgodnie z kalendarzem szczepień ochronnych. Zaobserwowano, że liczba posiadanych dzieci nie miała istotnego wpływu na realizację szczepień ochronnych. Według zdecydowanej większości (82\%) rodziców szczepionki nieobowiązkowe, nierefundowane powinny być ujęte w kalendarzu szczepień. Ponad połowa $(61,67 \%)$ badanych deklaruje, że nie korzysta ze szczepionek obowiązkowych, tylko kupuje szczepionki wieloskładnikowe, uzasadniając swoja decyzje mniejszą ilością dodatkowych substancji konserwujących.

Wnioski. 1) Rodzice chętnie poszerzają obowiązkowy kalendarz szczepień ochronnych o szczepienia zalecane. 2) Rodzice dostrzegają korzyści wynikające ze stosowania zalecanych szczepień ochronnych. 3) Wystąpienie odczynów poszczepiennych u dziecka determinuje decyzję rodziców o podejmowanych działaniach profilaktycznych w zakresie obowiązkowych i zalecanych szczepień ochronnych.

SŁOWA KLUCZOWE: szczepienia ochronne, odczyny poszczepienne, rodzice, wiedza.

\section{ABSTRACT}

Introduction. In Poland, vaccinations take place in medical entities and are run by doctors, nurses and midwives. Persons who have stayed within the territory of the Republic of Poland for over 3 months are obliged to undergo protective vaccinations against infectious diseases in accordance with the applicable Protective Vaccination Program.

Aim. The aim of the study was to identify factors determining the implementation of recommended immunization in children under 2 years of age.

Material and methods. The study involved 300 respondents (parents of children up to two years old), 91\% women and $9 \%$ men. The research was carried out in pediatric clinics and a family doctor in the city of Szczecin. The research was based on an author's questionnaire containing sociodemographic data and questions about immunization.

Results. Over $78.67 \%$ of parents surveyed reported that their child is vaccinated in accordance with the preventive vaccination calendar. It was observed that the number of children held did not have a significant impact on the implementation of immunization. According to the vast majority (82\%) of parents, non-compulsory vaccinations, not refunded, should be included in the vaccination calendar. Over half (61.67\%) of respondents declare that they do not use compulsory vaccines, only buy multi-component vaccines, justified their decision by a smaller amount of additional preservatives.

Conclusions. 1) Parents are eagerly expanding the mandatory immunization calendar for vaccinations recommended. 2) Parents demonstrate great knowledge of the benefits of using preventive vaccinations. 3) The occurrence of post-vaccination reactions in a child determines the parents' decision about the preventive measures taken in the field of mandatory and recommended vaccinations.

KEYWORDS: protective vaccinations, vaccination reactions, parents, knowledge. 


\section{Wprowadzenie}

Dynamiczny rozwój wakcynologii prowadzi do ograniczenia występowania chorób zakaźnych. Szczepionki stymulują do indukcji swoistej odpowiedzi immunologicznej przeciw określonym drobnoustrojom. Powstałe immunoglobuliny tworzą odporność czynną, która może trwać od kilku miesięcy do kilku lat [1].

Szczepionki, które zawierają antygeny jednego szczepu tego samego gatunku drobnoustroju (monowalentne) uodparniają przeciwko jednej chorobie [2, 3]. Szczepionki wieloskładnikowe (poliwalentne) zawierają antygeny kilku szczepów tego samego gatunku drobnoustroju [2, 3], natomiast szczepionki skojarzone zawierają dwa lub więcej antygenów i uodparniają organizm jednocześnie przeciwko kilku chorobom. Wprowadzenie szczepionek, w których występują różne patogeny, pozwoliło na ograniczenie liczby ukłuć podczas szczepienia [2, 3].

W Polsce funkcjonuje kalendarz szczepień obowiązkowych, dzięki któremu zachowana jest profilaktyka zdrowotna. Dostępne są również szczepienia zalecane, których koszt pokrywają rodzice i/lub opiekunowie prawni. Bezpłatnym szczepieniem zalecanym zostaje objęte dziecko, w którego przypadku istnieje duże ryzyko zachorowania np. dzieci uczęszczające do żłobka, klubiku dziecięcego [4].

W wyniku podania szczepionki w organizmie produkowane są przeciwciała i komórki odpornościowe, procesowi temu towarzyszy również powstanie odczynu poszczepiennego. Przyjmuje się, że jest to prawidłowa reakcja organizmu na podany preparat pochodzenia biologicznego. Zaawansowanie odczynu poszczepiennego zależy od indywidualnej reakcji organizmu oraz rodzaju i składu szczepionki [5]. Najczęściej w miejscu wkłucia obserwuje się odczyn o łagodnym charakterze, tj.: obrzęk, bolesność oraz zaczerwienienie [5].

Ze względu na możliwość wystąpienia gwałtownych reakcji poszczepiennych, każdy lekarz i/lub pielęgniarka ma obowiązek wnikliwej obserwacji pacjenta po wykonaniu szczepienia, a każda nietypowa reakcja na szczepienie musi zostać odnotowana w historii choroby pacjenta [6].

Czynniki prowadzące do powstania niepożądanego odczynu poszczepiennego można podzielić na: powiązane z działaniem szczepionki (indywidualna reakcja organizmu na szczepienie w postaci obrzęku, zaczerwienienia, wysypki, gorączki utrzymująca się do 48 godzin, reakcja anafilaktyczna po szczepieniu, trombocytopenia, porażenia wiotkie); powstałe w wyni- ku błędu szczepienia (nieprawidłowe przechowywanie, nieprzestrzeganie łańcucha chłodniczego); transportu i produkcji (zakażenie serii szczepionki); błędu w punkcie szczepień (nieprzestrzeganie aseptyki) oraz związane ze współistnieniem innych czynników (świeże zakażenie bezpośrednio po szczepieniu lub czas inkubacji choroby infekcyjnej lub zakaźnej) [7].

\section{Cel pracy}

Celem pracy było określenie czynników decydujących o realizacji zalecanych szczepień ochronnych u dzieci do 2 roku życia.

\section{Materiał}

Badanie zostało przeprowadzone w poradniach pediatrycznych i poradniach lekarzy rodzinnych na terenie Szczecina oraz w formie kwestionariusza internetowego. Badaniem objęto 300 rodziców/opiekunów dzieci do drugiego roku życia. Badane osoby były w wieku od 18 do 43 lat. Kobiety stanowiły większość wśród badanych, tj. 91\%. Najliczniejszą grupę wiekową prezentowały osoby od 18 do 29 lat (67,33\%), Zdecydowana większość badanych, to mieszkańcy dużych miast powyżej 100000 (71\%). Większość z badanych deklarowała wykształcenie wyższe (78,67\%).

\section{Metody badań}

W badaniu wykorzystano autorski kwestionariusz ankiety składający się z 24 pytań, obejmujący dane socjodemograficzne (wiek, płeć, miejsce zamieszkania, wykształcenie, wysokość dochodów, ilość potomstwa) a także pytania z zakresu szczepień ochronnych.

Do analizy statystycznej danych uzyskanych w wyniku przeprowadzonej ankiety wykorzystano program Statistica 12.5. Do oceny danych użyto testu KruskalaWallisa lub U Manna-Whitneya. Istotność statystyczna została określona przy wartości $p<0,05$.

\section{Wyniki}

$\mathrm{Na}$ realizację szczepień ochronnych zdecydowany wpływ miało wykształcenie rodziców, gdyż najchętniej swoje dzieci szczepili respondenci ze średnim wykształceniem $(90,40 \%)$.

Cena zalecanych szczepień ochronnych stanowiła powód rezygnacji z zaszczepienia dzieci ponad połowy badanych rodziców $(54,67 \%)$, natomiast obawy przed ewentualnymi powikłaniami wskazało $20,67 \%$ badanych (Rycina 1). 


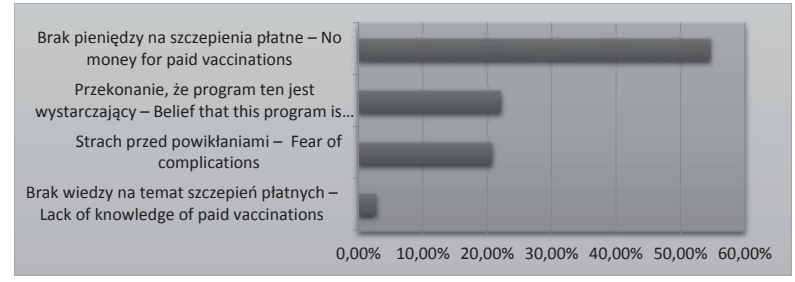

Rycina 1. Powody korzystania wyłącznie z programu szczepień obowiązkowych

Figure 1. The causes of using only mandatory vaccines

Źródło: opracowanie własne

Source: author's own analysis

Zdecydowana większość ankietowanych uważa szczepienia ochronne za bezpieczne dla dziecka (90\%) (Rycina 2). Głównym motywem decyzji rodziców o poddaniu dziecka nieobowiązkowym szczepieniom była chęć zabezpieczenia przed chorobami (78,33\%), w najmniejszym stopniu na decyzję rodziców wpływało wprowadzenie programu 500+ (1,33\%) (Rycina 3). Do najczęściej wybieranych przez respondentów szczepień dodatkowych należały szczepienia przeciw rotawirusom (78\%), meningokokom (55\%) i grypie (1,33\%), (Rycina 4).

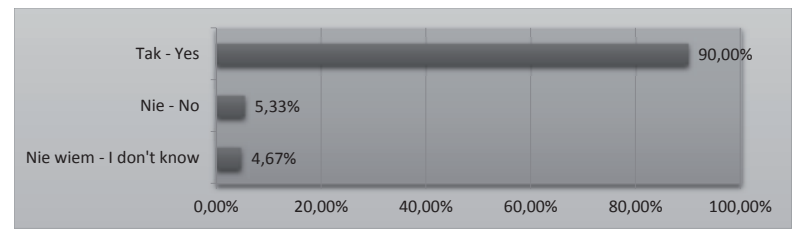

Rycina 2. Opinia rodziców na temat bezpieczeństwa szczepienia Figure 2. The parents' opinions about the safety of vaccinations Źródło: opracowanie własne Source: author's own analysis

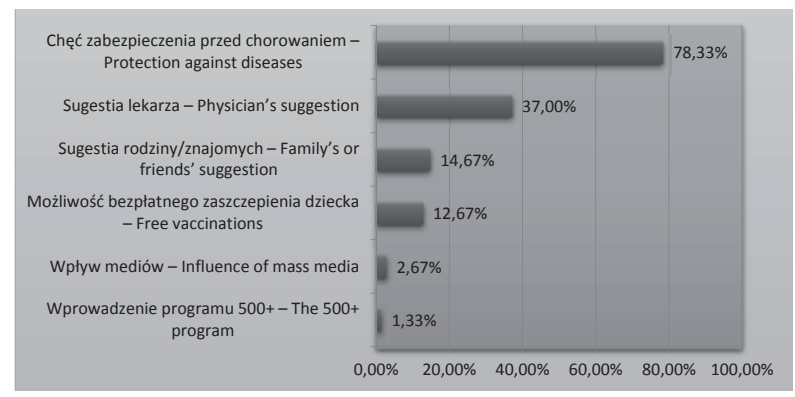

Rycina 3. Motywy zaszczepienia dziecka szczepionkami zalecanymi Figure 3. Motives for giving children recommended vaccines Źródło: opracowanie własne Source: author's own analysis

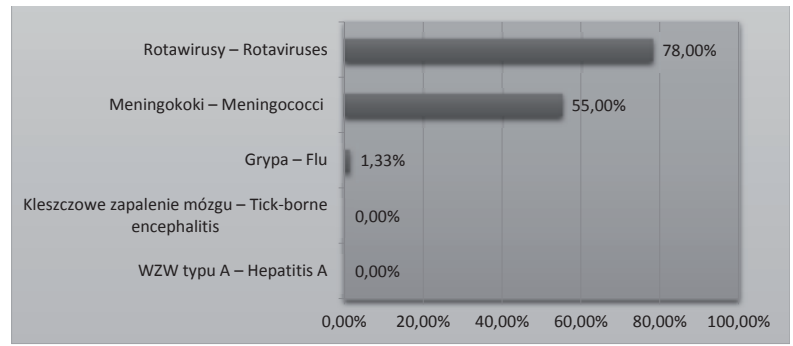

Rycina 4. Najczęściej zakupywana przez rodziców szczepionka zalecana Figure 4. The most often bought recommended vaccination

Źródło: opracowanie własne

Source: author's own analysis

Wiedza rodziców na temat szczepień dodatkowych najczęściej pochodziła od pracowników ochrony zdrowia, głównie od lekarzy $87,33 \%$, pielęgniarek $67 \%$ i położnych 28,67\%. Znaczna część rodziców informacje w tym zakresie czerpała $z$ Internetu $39,33 \%$ oraz doświadczenia innych rodziców - 38,67\% (Rycina 5).

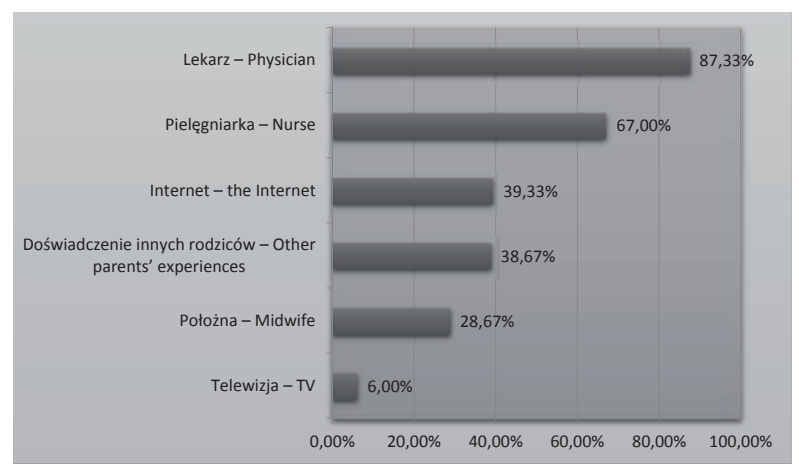

Rycina 5. Źródło wiedzy rodziców na temat szczepień ochronnych Figure 5. The sources of the parents' knowledge of vaccinations Źródło: opracowanie własne Source: author's own analysis

Jedynie 44,33\% rodziców było poinformowanych przez lekarza o możliwych skutkach ubocznych szczepienia, natomiast $61,33 \%$ zauważyło u swoich dzieci wystąpienie niepożądanego odczynu poszczepiennego (NOP). Najczęściej obserwowanymi objawami były miejscowy obrzęk (42,67\%), zaczerwienienie (41,67\%), ból w miejscu ukłucia (23,00\%), gorączka (21,67\%), powiększenie węzłów chłonnych (10,67\%) oraz niepokój (9,67\%).

Wystąpienie NOP w istotny sposób wpływało na realizację szczepień ochronnych, przy czym w przypadku wystąpienia takiego odczynu rodzice częściej odstępowali od realizacji szczepień (30,90\%) (Tabela 1). 
Tabela 1. Wpływ wystąpienia niepożądanego odczynu poszczepiennego u dziecka na realizację szczepień ochronnych

Table 1. The influence of an adverse vaccination reaction in the child to continue vaccinations

\begin{tabular}{|c|c|c|c|c|}
\hline \multirow{3}{*}{$\begin{array}{c}\text { Wystąpienie } \\
\text { niepożądanego } \\
\text { odczynu poszczepiennego/ } \\
\text { An adverse vaccination } \\
\text { reaction }\end{array}$} & \multicolumn{4}{|c|}{$\begin{array}{l}\text { Odstąpienie od realizacji szczepienia/ } \\
\text { Refraining from further vaccinations }\end{array}$} \\
\hline & Tak/Yes & Nie/No & \multirow{2}{*}{$\lambda^{2}$} & \multirow{2}{*}{$p$} \\
\hline & $\%$ & $\%$ & & \\
\hline Tak/Yes & 30,90 & 69,10 & & $(=0,000001)$ \\
\hline Nie/No & 6,70 & 93,30 & 28,42 & $<0,05$ \\
\hline
\end{tabular}

p - istotność statystyczna, \% - procent, $\lambda^{2}$ - test Kruskala-Wallisa

$p$-statistical significance, \% - percent, $\lambda^{2}$ - the Kruskal-Wallis test

Źródło: opracowanie własne

Source: author's own analysis

Chęć zabezpieczenia dziecka przed zachorowaniem była istotnie zależna od miejsca zamieszkania, wykształcenia oraz sytuacji materialnej $(p<0,05)$. Wykazano, że decyzja wynikająca z sugestii lekarza jest istotnie zależna od sytuacji materialnej $(p<0,05)$, natomiast decyzja wynikająca z sugestii rodziny/znajomych od miejsca zamieszkania, wykształcenia oraz sytuacji materialnej. Możliwość bezpłatnego szczepienia jest zależna od miejsca zamieszkania i sytuacji materialnej rodziny (Tabela 2 ).

Tabela 2. Wpływ wybranych zmiennych na decyzję o wyborze szczepionki zalecanej

Table 2. The influence of selected variables on a decision to use the recommended vaccine

\begin{tabular}{|c|c|c|c|c|c|c|c|}
\hline \multirow[t]{2}{*}{$\begin{array}{c}\text { Zmienna/ } \\
\text { Variable }\end{array}$} & \multirow[t]{2}{*}{$\begin{array}{c}\text { Cecha/ } \\
\text { Characteristic }\end{array}$} & 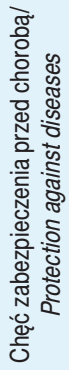 & 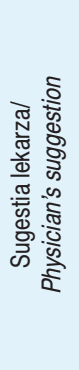 & 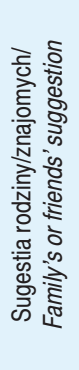 & 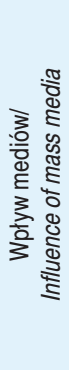 & 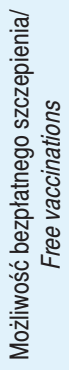 & 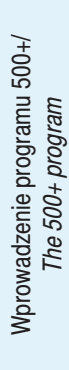 \\
\hline & & $\%$ & $\%$ & $\%$ & $\%$ & $\%$ & $\%$ \\
\hline \multirow{5}{*}{$\begin{array}{c}\text { Miejsce } \\
\text { zamieszkania/ } \\
\text { Place } \\
\text { of residence }\end{array}$} & $\begin{array}{l}\text { miasto od } 10.000- \\
100.000 / \\
\text { city of } 10.000- \\
100.000 \text { residents }\end{array}$ & 11,06 & 19,82 & 2,27 & 0,00 & 34,22 & 0,00 \\
\hline & $\begin{array}{c}\text { miasto powyżej } \\
100.000 / \\
\text { city of over } 100.000 \\
\text { residents }\end{array}$ & 70,40 & 63,96 & 79,55 & 100,00 & 63,16 & 100,00 \\
\hline & $\begin{array}{l}\text { miasto do } 10000 / \\
\text { city of up to } 10.000 \\
\text { residents }\end{array}$ & 14,04 & 13,51 & 18,18 & 0,00 & 2,63 & 0,00 \\
\hline & wieś/rural areas & 4,50 & 2,70 & 0,00 & 0,00 & 0,00 & 0,00 \\
\hline & $p$ & $<0,05$ & $>0,05$ & $<0,05$ & $>0,05$ & $<0,05$ & $>0,05$ \\
\hline
\end{tabular}

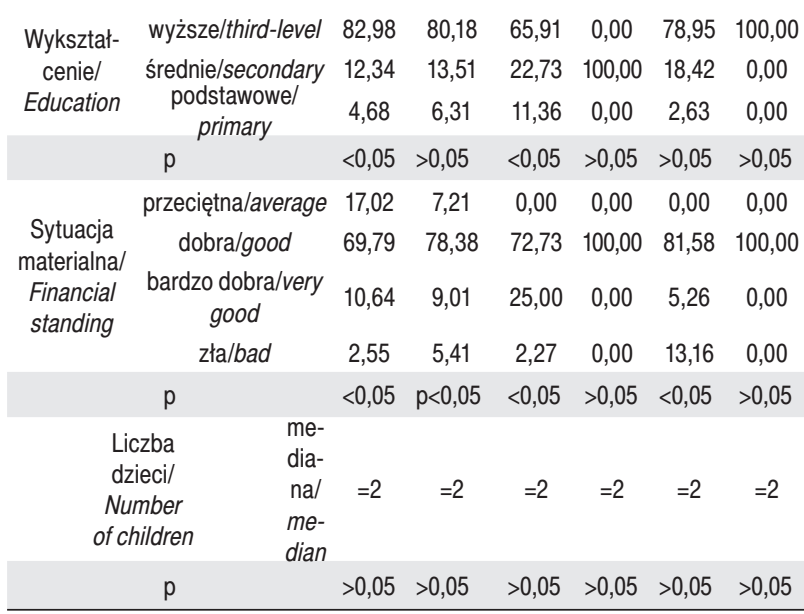

$\mathrm{p}$ - istotność statystyczna, $\%$ - procent $/ \mathrm{p}$ - statistical significance, $\%$ - percent

Źródło: opracowanie własne

Source: author's own analysis

\section{Dyskusja}

Rozwój wakcynologii umożliwia uodpornienie społeczeństwa na choroby zakaźne. Dostępność szczepionek skojarzonych oraz odpłatnych szczepień zalecanych przyczynia się do profilaktyki na szeroką skalę. Coraz większa świadomość ryzyka związanego z występowaniem schorzeń zakaźnych prowadzi do wzrostu akceptacji szczepień ochronnych, jednak właściwa realizacja programu szczepień jest uzależniona od dostępności i zrozumienia przekazywanych informacji w tym zakresie szerokiej populacji [8]. Badania przeprowadzone w Arabii Saudyjskiej wykazały, że najważniejszym czynnikiem odpowiedzialnym za zaniechanie zalecanych szczepień w grupie chorych na cukrzycę był brak wiedzy (95\%), a najlepszym motywatorem była porada (wskazanie) przedstawicieli zawodów medycznych $84,7 \%$ [10]. Polscy autorzy również wskazują na istotną rolę pracowników ochrony zdrowia jako głównego i najbardziej wiarygodnego źródła informacji [8, 11-12]. Według Gańczak i wsp. [11] 89,3\% rodziców uzyskało informacje od pracowników ochrony zdrowia, natomiast z mediów tylko 11,4\%. Z danych przedstawionych przez Kochman i Rudzińską wynika, że 79,1\% rodziców uzyskało wiedzę od lekarza, $66,4 \%$ od pielęgniarki, 30\% od położnej, natomiast dane ze środków społecznego przekazu pozyskało tylko 15,5\% ankietowanych [8]. Gańczak i wsp. [11] wykazują również, że zalecenie i opinia pracowników ochrony zdrowia ma najistotniejszy wpływ na podjęcie decyzji o zaszczepieniu dziecka, gdyż 82,3\% rodziców deklarowało podjęcie decyzji w oparciu o ich poradę (edukację). Według Kochman i Rudzińskiej [8] informacje dotyczące szczepień były najbardziej przekonujące, gdy były przekazywane przez lekarza (69,1\%) i pielęgniarkę (19,1\%). Położna 
pomogła w podjęciu ostatecznej decyzji 5,9\% matek. Jackowska i Kłyszewska [12] wykazały, że informacje o co najmniej trzech szczepieniach zalecanych posiadało $82 \%$ rodziców, a najlepiej znanym szczepieniem było szczepienie przeciwko Streptococcus pneumoniae. Wyniki te są zbieżne z omawianymi badaniami.

Jednym z głównych powodów, dla których rodzice odstępowali od zaszczepienia swoich dzieci był lęk przed powikłaniami związanymi ze szczepieniem. Ślusarczyk [14] wykazała, że negatywne opinie na temat szczepień ochronnych skupiają się wokół braku skuteczności i bezpieczeństwa preparatów (zawartość rtęci, nadmierne obciążenie układu odpornościowego dziecka oraz ryzyko wystąpienia autyzmu czy chorób np.: nowotworów). Podobne wnioski wyciągnęła Dybowska [15] wykazując, że rodzice najbardziej obawiali się ryzyka wystąpienia licznych powikłań i odczynów poszczepiennych. W badaniach przeprowadzonych w Warszawie i Tallinie zdecydowana większość rodziców miała wątpliwości odnośnie bezpieczeństwa szczepionek (w Polsce $62 \%$, w Estonii $70 \%$ ) natomiast $62 \%$ respondentów z Estonii i 64\% z Polski obawiało się skutków ubocznych szczepień [16]. Podobnie wśród diabetyków poddanych szczepieniu przeciw grypie największą barierę stanowił lęk przed wystąpieniem efektów ubocznych 73\% [10]. Jackowska i Kruszewska [12] stwierdziły na podstawie obserwacji, że większość rodziców akceptuje szczepienia pomimo swoich obaw. Podobne wyniki otrzymano na podstawie badań własnych. Rodzice, u których dzieci wystąpiły NOP, częściej rezygnowali ze szczepionek zalecanych, a 20,67\% korzystających wyłącznie z darmowego programu szczepień decyzję swoją tłumaczyło lękiem przed wystąpieniem powikłań pomimo, że tylko około 10 \% rodziców uważało szczepienia za niebezpieczne lub nie miało wiedzy na ten temat.

Według Gańczak i wsp. [11] istotnym czynnikiem determinującym wykonanie u dzieci zalecanych szczepień ochronnych był status socjoekonomiczny; w grupie osób deklarujących status socjoekonomiczny na poziomie dobrym lub średnim 83\% kupiło dodatkowe szczepienia, natomiast w grupie o niskich dochodach tylko $46,5 \%$. Badacze wskazują również na znaczenie ceny szczepionek, ponieważ była ona poważną przeszkodą dla 20,1\% rodziców, a 59,5\% z nich deklarowało, że nie było w stanie samodzielnie wykupić żadnej szczepionki. Jackowska i Kłyszewska również wykazały, że w 67\% przypadków powodem braku realizacji szczepień zalecanych był ich wysoki koszt [12]. Hoffman i wsp. [17] przedstawili badania, z których wynika, że wprowadzenie przez samorządy bezpłatnych dobrowolnych programów szczepień przeciw grypie do szkół przyczyniło się do znacznego wzrostu ilości zaszczepionych dzieci.
Status socjoekonomiczny ma wpływ również na korzystanie z obowiązkowego programu szczepień, gdyż na terenie Bytomia wśród rodzin określających swój status jako dobry odsetek niezaszczepionych dzieci wynosi $0,7 \%$ natomiast wśród rodzin ze złą sytuacją materialną - aż 2,6\% [18].

Wyniki badań własnych wykazują podobną tendencję do rezygnacji z zaszczepienia dzieci z powody zbyt wysokiej ceny szczepionek zalecanych oraz niskiego statusu socjoekonomicznego.

Z przeprowadzonych badań własnych wynika, że wystąpienie niepożądanego odczynu poszczepiennego wpływa w istotny sposób na rezygnację z szczepienia dziecka. Do najczęściej występujących NOP należą odczyny o niewielkim nasileniu, jak ból w miejscu wkłucia czy zaczerwienienie i obrzęk. Podobne wyniki przedstawiła Dybowska [15], gdyż najczęściej zgłaszany był miejscowy odczyn w postaci zaczerwienienia $28 \%$, miejscowy obrzęk $29 \%$ oraz ból w miejscu ukłucia $15 \%$. Odczyny łagodne, miejscowe lub uogólnione pojawiają się najczęściej, natomiast rzadziej zdarzają się ciężkie powikłania.

Szczepienia ochronne stanowią fundament zdrowia populacji. Rodzice mają coraz większą świadomość ryzyka związanego z chorobami zakaźnymi jak również korzyści płynących z zastosowania szczepień ochronnych. Z tego powodu znaczna ich część zgłasza chęć zaszczepienia dziecka szczepionką zalecaną. Niestety, często koszt szczepień zalecanych jest zbyt duży, przez co nie są one dostępne w wystarczającym stopniu. Pomimo wzrastającej świadomości w dalszym ciągu występują wątpliwości odnośnie bezpieczeństwa szczepionek, a wystąpienie niepożądanych odczynów poszczepiennych jest ważną przyczyną odstąpienia od dalszego szczepienia dziecka.

\section{Wnioski}

1. Rodzice chętnie poszerzają obowiązkowy kalendarz szczepień ochronnych o szczepienia zalecane.

2. Rodzice dostrzegają korzyści wynikające ze stosowania zalecanych szczepień ochronnych.

3. Wystąpienie odczynów poszczepiennych u dziecka determinuje decyzję rodziców o podejmowanych działaniach profilaktycznych w zakresie obowiązkowych i zalecanych szczepień ochronnych.

\section{Piśmiennictwo}

1. Krawczyński M. Propedeutyka pediatrii. Warszawa: Wydawnictwo Lekarskie PZWL; 2009. 423-449.

2. Mort M, Baleta A, Destefano F, Nsubuga JG, Vellozzi C, Mehta U, i wsp. Vaccine Safety Basics lerning manual. [on- 
line]. Geneva: World Health Organisation; 2013. 18-19. [Dostęp: 2 lipca 2017]. Dostępny w: https://www.who.int/vaccine_safety/initiative/tech_support/Vaccine-safety-E-coursemanual.pdf.

3. Szczeklik A, Gajewski P. Interna Szczeklika. Kraków: Med Prakt; 2014. 2388-2391.

4. Program Szczepień Ochronnych na rok 2018. [online]. Załącznik do Komunikatu Głównego Inspektora Sanitarnego w sprawie zasad przeprowadzania szczepień ochronnych przeciw chorobom zakaźnym w 2018 r. [Dostęp: 31.05. 2018]. Dostępny w: https://szczepienia.gis.gov.pl/pliki/Komunikat\%20GIS\%20w\%20sprawie\%20PSO\%20na\%20 2018\%20r..pdf.

5. Czajka H, Wysocki J. Szczepienia w profilaktyce chorób zakaźnych. Kraków: Help-Med S.c.; 2010. 3-4.

6. Gołąb J, Stokłosa T, Grzesiowski P, Hryniewicz W, Nowis D. Odporność przeciwzakaźna. W: Gołąb J, Jakóbisiak M, Lasek W, Stokłosa T. (Red) Immunologia. Warszawa: Wydawnictwo PWN; 2012. 305-342.

7. Magdzik W, Naruszewicz-Lesiuk D, Zieliński A. Wakcynologia. Bielsko-Biała: Alfa Medica Press; 2007. 88-94.

8. Kochman D, Rudzińska T. Analiza decyzji rodziców o poddaniu szczepieniom dzieci w wieku 0-2 lat. Pediatr Pol. 2008; 44(4): 357-362.

9. Knuf M. A combination vaccine against measles mumps, rubella and varicella. Drugs 2008; 44(4):

10. Alnaheelah IM, Awadalla NJ, Al-Musa KM, Alsabaani AA, Mahfouz AA. Influenza vaccination in type 2 diabetes patient: coverage status and its determinants in southwestern Saudi Arabia. [online]. Int J Environ Res Public Health. 2018; 15(7): 1381. [Dostęp: 31.05.2018]. Dostępny w: http://www. mdpi.com/1660-4601/15/7/1381/htm.

11. Gańczak M, Dmytrzyk-Daniłów G, Karakiewicz B, Korzeń $M$, Szych $Z$. Determinants influencing self-paid vaccination coverage, in 0-5 years old Polish children. Vaccine. 2013; 31(48): 5687-5692.

12. Jackowska T, Kłyszewska M. Realizacja szczepień zalecanych u dzieci i ocena świadomości ich rodziców. Pediatr Pol. 2010; 85(3): 201-206.
13. Kochman D, Rudzińska T. Analiza przyczyn decyzji rodziców o poddaniu szczepieniom dzieci w wieku 0-2 lat. Pediatr Pol. 2008; 83(4): 357-362.

14. Ślusarczyk J. Współczesne szczepionki nowym narzedziem w zapobieganiu chorobom zakaźnym. Zakażenia. 2005; 5(5): 100-104.

15. Dybowska D. Kleszczowe zapalenie mózgu - obraz kliniczny i zapobieganie. Essentia Medica. 2007; 30(6). 59-62.

16. Klotsko M, Walewska-Zielecka B, Olejniczak D, Skonieczna J. Wiedza i deklarowane postawy rodziców wobec szczepień ochronnych dla dzieci w Warszawie i Tallinie. J Educ Health Sport. 2015; 5(12): 89-98.

17. Hoffman L, Sapilak BJ, Hans-Wytrychowska A. Szczepienia ochronne obowiązkowe i zalecane w praktyce lekarza rodzinnego NZOZ „Zdrowie” w Pleszewie obejmujące populację dzieci i młodzieży do 19 r.ż - analiza wyszczepialności i próba oceny czynników wpływających na jej wzrost. Fam Med Primary Care Rev. 2009; 11(3): 337-340.

18. Hubicki L, Czech E, Kowalska M, Zejda JE. Szczepienia ochronne dzieci w rodzinach o różnym stanie społecznoekonomicznym w Bytomiu. Przegl Epidemiol. 2004; 58(4): 713-723.

Artykuł przyjęty do redakcji: 10.10.2018.

Artykuł przyjęty do publikacji: 20.02.2019.

Źródło finansowania: Praca nie jest finansowana z żadnego źródła. Konflikt interesów: Autorzy deklarują brak konfliktu interesów.

\section{Adres do korespondencji:}

Anna Katarzyna Kędzierska

ul. Żołnierska 48 Bud. 8

71-210 Szczecin

tel. 914800932

e-mail: anna.kedzierska@pum.edu.pl

Zakład Pielęgniarstwa Specjalistycznego, Pomorski Uniwersytet Medyczny w Szczecinie 